\title{
Carrot Phytoalexin Alters the Membrane Permeability of Candida albicans and Multilamellar Liposomes
}

\author{
By MAGDY AMIN, FUMIYA KUROSAKI AND ARASUKE NISHI* \\ Faculty of Pharmaceutical Sciences, Toyama Medical and Pharmaceutical University, Sugitani, \\ Toyama 930-01, Japan
}

(Received 6 May 1987; revised 17 August 1987)

\begin{abstract}
The biochemical basis for the antimicrobial effect of the carrot phytoalexin 6-methoxymellein (6-MM) was examined. At fungistatic concentrations 6-MM retarded the ability of Candida albicans to incorporate radioactive thymidine, uridine and leucine into biopolymers. When $C$. albicans was incubated with 6-MM, 260-nm-absorbing materials and ${ }^{3} \mathrm{H}$-labelled compounds leaked from the cells. The inhibitory effects of 6-MM on cell growth and membrane functions were, however, reduced as the concentration of divalent metal cations added to the medium was increased. 6-MM interacted with multilamellar liposomes constituted from phosphatidylcholine, cholesterol and dicetyl phosphate, or from phosphatidylcholine only, resulting in the release of glucose trapped in these liposomes. These results suggest that 6-MM exerts its toxic effects on susceptible cells as a result of its interaction with their membranes and disturbance of membrane-associated functions.
\end{abstract}

\section{INTRODUCTION}

Phytoalexins are host-synthesized, low-molecular-mass antibiotic compounds whose synthesis from distant precursors is induced in plants in response to microbial infection or treatment of plant tissues with a wide range of naturally occurring or synthetic compounds called elicitors (Dixon \& Key, 1983). The mechanism of action of phytoalexins is not fully understood though some evidence suggests that they alter the properties of the plasma membrane (Hargreaves, 1980; Weinstein \& Albersheim, 1983). It has also been reported that some phytoalexins inhibit electron transport in mitochondria (Kaplan et al., 1980; Boydston et al., 1983).

The carrot phytoalexin 6-MM is toxic to a wide range of organisms. It inhibits the growth of bacteria, fungi (Kurosaki \& Nishi, 1983), and animal and plant cells (Coxon et al., 1973; Kurosaki et al., 1984). The mechanism by which 6-MM stops the growth of cells is not yet understood, though recently we have shown that it inhibits basal and calmodulin-stimulated activity of bovine cyclic nucleotide phosphodiesterase (PDE) (Amin et al., 1986) and calcium/ calmodulin-dependent protein phosphorylation in cultured carrot cells (Amin et al., 1987). In this paper, we report on the effect of 6-MM on cell permeability of a pathogenic strain of Candida albicans, and on its interaction with multilamellar liposomes.

\section{METHODS}

Micro-organism and culture. Candida albicans strain ATCC 18804 was grown on yeast nitrogen base (Difco) supplemented with $0.5 \%(\mathrm{w} / \mathrm{v})$ glucose. Cell growth was followed by measuring the optical density of cultures at $595 \mathrm{~nm}$. Cultures in the early exponential growth phase were used for experiments. Cell density at the beginning of experiments was $1.5-2.5 \times 10^{6}$ cells $\mathrm{ml}^{-1}$.

Isolation and purification of 6-MM. 6-MM was isolated and purified from carrot root slices infected by the fungus Chaetomium globosum, as described by Kurosaki \& Nishi (1983). 6-MM was dissolved in ethanol and was added to cultures to a final concentration of $0.1-0.5 \mathrm{~mm}$. The ethanol concentration was adjusted to $1 \%$. Controls contained the same ethanol concentration.

Abbreviations: 6-MM, 6-methoxymellein; PDE, phosphodiesterase. 
Incorporation of ${ }^{3} \mathrm{H}$-labelled metabolites. [methyl $\left.{ }^{-3} \mathrm{H}\right] \mathrm{Thymidine}\left[13 \cdot 0 \mathrm{Ci} \mathrm{mmol}^{-1}\left(481 \mathrm{GBq} \mathrm{mmol}^{-1}\right)\right],\left[5-{ }^{3} \mathrm{H}\right]-$ uridine $\left[26.6 \mathrm{Ci} \mathrm{mmol}^{-1}\left(984.2 \mathrm{GBq} \mathrm{mmol}^{-1}\right)\right]$ and $\mathrm{L}-\left[4,5{ }^{-3} \mathrm{H}\right]$ leucine $\left.\left[60.0 \mathrm{Ci} \mathrm{mmol}^{-1} 2.22 \mathrm{TBq} \mathrm{mmol}^{-1}\right)\right]$ were obtained from New England Nuclear. Incorporation of these radioactive precursors into biopolymers of $C$. albicans was determined as described by Fraser \& Creanor (1974). Isotopes were added to the cultures to a concentration of $0.5-1 \mu \mathrm{Ci} \mathrm{ml}^{-1}\left(18.5-37 \mathrm{kBq} \mathrm{ml}^{-1}\right)$. At intervals, $0.5 \mathrm{ml}$ samples of the cultures were taken out and mixed with $5 \mathrm{ml}$ ice-cold $10 \%(\mathrm{w} / \mathrm{v})$ trichloroacetic acid (TCA). The cells were collected by filtration on Whatman GF/A glass-microfibre filter paper and washed three times with $5 \%(\mathrm{w} / \mathrm{v}) \mathrm{TCA}$. Acid-insoluble radioactivities on the dried filters were measured by liquid scintillation spectrometry using a commercial scintillation liquid, ACS II.

Leakage of 260-nm-absorbing materials. To a sample $(3 \mathrm{ml})$ of a suspension of C. albicans in a salts solution $\left[\left(\mathrm{NH}_{4}\right)_{2} \mathrm{SO}_{4}, 0.5 \%(\mathrm{w} / \mathrm{v}) ; \mathrm{K}_{2} \mathrm{HPO}_{4} 0.1 \%(\mathrm{w} / \mathrm{v}) ; \mathrm{MgSO}_{4} .7 \mathrm{H}_{2} \mathrm{O}, 0.05 \%(\mathrm{w} / \mathrm{v}) ; \mathrm{NaCl}, 0.01 \%(\mathrm{w} / \mathrm{v})\right.$ and $\mathrm{CaCl}_{2}$. $\left.6 \mathrm{H}_{2} \mathrm{O}, 0.01 \%(\mathrm{w} / \mathrm{v}) ; \mathrm{pH} 5 \cdot 5\right], 6-\mathrm{MM}(10 \mu 1)$ was added. The suspension was kept on a reciprocal shaker at $27^{\circ} \mathrm{C}$, then centrifuged at $1500 \mathrm{~g}$ for $15 \mathrm{~min}$; the resulting supernatant was then centrifuged for $10 \mathrm{~min}$. 6-MM in the supernatant was extracted twice with hexane and the absorbance at $260 \mathrm{~nm}$ of the aqueous layer was recorded.

Leakage of ${ }^{3} \mathrm{H}$-labelled metabolites. C. albicans cells were collected by centrifugation and resuspended in fresh medium containing $\left[{ }^{3} \mathrm{H}\right]$ thymidine, $\left[{ }^{3} \mathrm{H}\right]$ uridine or $\left.\mathrm{L}-{ }^{3} \mathrm{H}\right]$ leucine $\left[1 \mu \mathrm{Ci} \mathrm{m} l^{-1}\left(37 \mathrm{kBq} \mathrm{ml}{ }^{-1}\right)\right]$. The cells were incubated with these labelled metabolites for $2 \mathrm{~h}$ on a reciprocal shaker at $27^{\circ} \mathrm{C}$. Cells were collected by centrifugation, washed three times with water and resuspended in water to which 6-MM was added. At intervals, $0.5 \mathrm{ml}$ samples of the cell suspension were filtered using Whatman GF/A glass-microfibre filters. The filters were then washed with water $(1 \mathrm{ml})$ and the radioactivities of the filtrates were measured.

Preparation of liposomes. Multilamellar liposomes were prepared by the technique of Bangham $e$ t al. (1965). The liposomes consisted of egg-yolk phosphatidylcholine or phosphatidylcholine, dicetyl phosphate and cholesterol (molar ratio 10:1:5). These materials were purchased from Sigma. The dried lipid film, in a $50 \mathrm{ml}$ round bottom flask, was swollen in $0.5 \mathrm{ml} 0.3 \mathrm{M}$-glucose containing $0.5 \mu \mathrm{Ci}(18.5 \mathrm{kBq}) \mathrm{D}-\left[\mathrm{U}-{ }^{14} \mathrm{C}\right] \mathrm{glucose}$ as a marker. Untrapped glucose was removed by dialysing the liposome suspension at room temperature against isotonic $(0.85 \%, \mathrm{w} / \mathrm{v})$ saline solution for $5 \mathrm{~h}$ (five changes, 21 each). The liposome suspension was then diluted with isotonic saline solution to give a final concentration of $0 \cdot 1 \mu \mathrm{mol}$ phosphatidylcholine ( $\mathrm{ml} \mathrm{saline})^{-1}$.

Measurement of liposomal permeability. The permeability of liposomes was estimated from the rate of release of the trapped $\mathrm{D}-\left[{ }^{14} \mathrm{C}\right]$ glucose. The $\left[{ }^{14} \mathrm{C}\right]$ glucose released in the aqueous solution was separated from the liposomes by the membrane filtration method described by Oku et al. (1980) using a $10 \mathrm{ml}$ glass syringe equipped with a membrane filter unit (Millipore filter type GS; pore size $0 \cdot 2 \mu \mathrm{m}$ ). The extent of 6-MM-induced release of glucose is expressed as percentage glucose release and was calculated as follows (HsuChen \& Feingold, 1973).

$$
\text { Percentage glucose released }=\frac{\left[{ }^{14} \mathrm{C} \text { glucose released in the presence of 6-MM }-\right. \text { blank control }}{\text { total amount of }\left[{ }^{14} \mathrm{C} \text { glucose trapped }-\right. \text { blank control }}
$$

The total amount of $\left[{ }^{14} \mathrm{C}\right]$ glucose trapped was determined by adding $0.5 \mathrm{ml} 10 \%(\mathrm{v} / \mathrm{v})$ Triton X-100 to $0.5 \mathrm{ml}$ liposomes and heating in a boiling water bath for a few minutes before measurement of the radioactivity. The $\left[{ }^{14} \mathrm{C}\right]$ glucose released by $6-\mathrm{MM}$ was determined by incubating $0.5 \mathrm{ml}$ liposomes with $10 \mu \mathrm{l}$ 6-MM in dimethyl sulphoxide (DMSO) or DMSO only (blank control) for $30 \mathrm{~min}$ at $22 \pm 2{ }^{\circ} \mathrm{C}$. Liposomes were then diluted to $3 \mathrm{ml}$ with isotonic saline and transferred to a glass syringe; $1.5 \mathrm{ml}$ of this suspension was then filtered through a membrane filter and the $\left[{ }^{14} \mathrm{C}\right] \mathrm{glucose}$ in the filtrate was determined by measuring the radioactivity.

\section{RESULTS AND DISCUSSION}

\section{Effect of 6-MM on the synthesis of macromolecules in C. albicans}

6-MM retarded equally the ability of $C$. albicans to incorporate the ${ }^{3} \mathrm{H}$-labelled metabolites into biopolymers (Fig. 1). At the minimum inhibitory concentration for growth of 6-MM $(0.5 \mathrm{~mm})$ there was a 6-10 min lag before detectable inhibition of the incorporation of $\left[{ }^{3} \mathrm{H}\right]-$ thymidine, $\left[{ }^{3} \mathrm{H}\right]$ uridine and $\left[{ }^{3} \mathrm{H}\right]$ leucine into their respective macromolecules; the time lag was longer when the phytoalexin was applied at lower concentration. The existence of the time lag and the fact that a relatively high concentration of 6-MM was required for significant inhibition of the incorporation of these precursors rules out the possibility that 6-MM is a specific inhibitor of nucleic acid or protein synthesis. A similar conclusion was reported for the pterocarpan phytoalexin glycinol (Weinstein \& Albersheim, 1983). The decrease in rate of incorporation of the metabolites might result from their reduced uptake from the medium into the cells. 

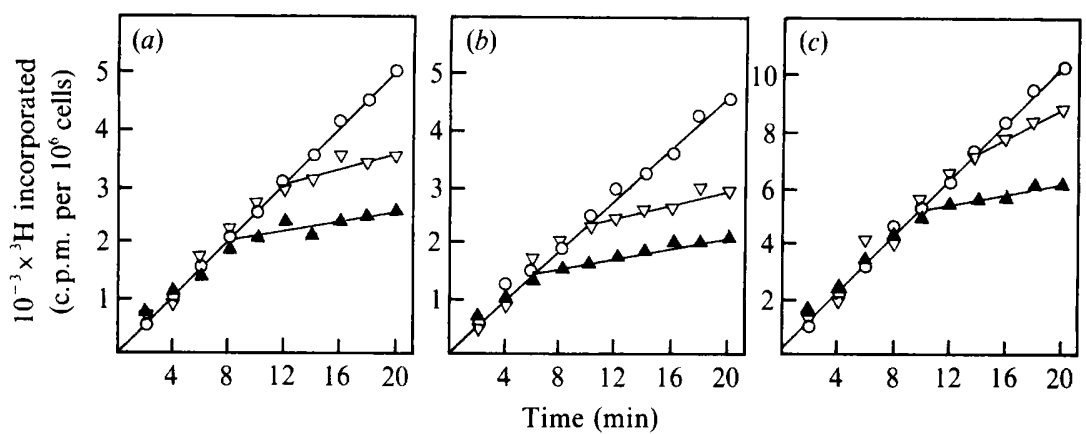

Fig. 1. Effect of 6-MM on the incorporation of $(a)\left[{ }^{3} \mathrm{H}\right]$ thymidine, $(b)\left[{ }^{3} \mathrm{H}\right]$ uridine and $(c)\left[{ }^{3} \mathrm{H}\right]$ leucine into biopolymers in C. albicans. At the indicated intervals, samples of the cultures were taken, mixed with cold $10 \%(\mathrm{w} / \mathrm{v}) \mathrm{TCA}$, filtered through glass-microfibre filters and washed with $5 \%(\mathrm{w} / \mathrm{v}) \mathrm{TCA}$. The radioactivity on the dried filters was counted. $O$, Control; $\nabla, 6-\mathrm{MM}(0.1 \mathrm{mM}) ; \Delta, 6-\mathrm{MM}(0.5 \mathrm{mM})$. Each point represents the mean of three separate experiments with \pm SE less than $10 \%$ of the mean.

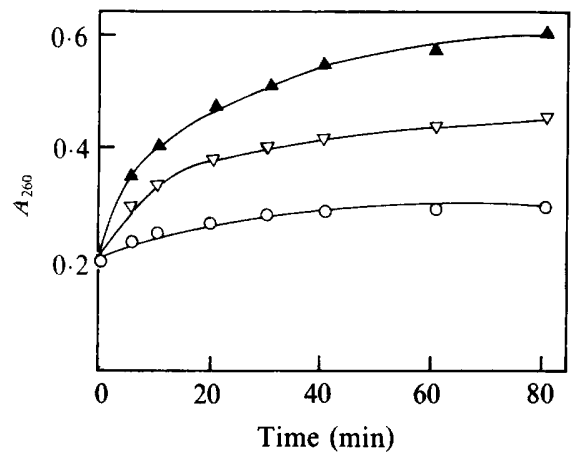

Fig. 2. Effect of 6-MM on the leakage of 260-nm-absorbing materials from C. albicans. Washed cells of C. albicans werc suspended in a buffered salt solution. After the addition of 6-MM, the cell suspensions were incubated at $27^{\circ} \mathrm{C}$ on a reciprocal shaker. At intervals, samples of suspensions were centrifuged and the supernatants were extracted twice with hexane to remove 6-MM. The absorbance at $260 \mathrm{~nm}$ of the aqueous solutions was measured. $O$, Control; $\nabla, 6-\mathrm{MM}(0 \cdot 1 \mathrm{mM}) ; \Delta, 6-\mathrm{MM}(0.5 \mathrm{mM})$. Each point represents the mean of three separate experiments with \pm SE less than $10 \%$ of the mean.

\section{Effect of 6-MM on cell permeability}

Cells incubated with 6-MM leaked 260-nm-absorbing materials (Fig. 2). This suggested that 6-MM might bind to the cell membrane and alter the membrane permeability, a view confirmed as follows. When the cells were labelled with $\left[{ }^{3} \mathrm{H}\right]$ thymidine, $\left[{ }^{3} \mathrm{H}\right]$ uridine or $\left[{ }^{3} \mathrm{H}\right]$ leucine and then incubated with 6-MM, the cells leaked ${ }^{3} \mathrm{H}$-labelled metabolites (Fig. 3). Loss of labelled metabolites from cells and increase in conductivity of the incubation medium have previously been reported for some phytoalexins (Smith, 1982), membrane acting antibiotics (Storm et al., 1977) and chemotherapeutic agents (Swamy et al., 1974).

\section{Reversal of 6-MM action by metal cations}

We have previously shown that 6-MM inhibited basal and calmodulin-stimulated PDE, and that $\mathrm{Mg}^{2+}$ and $\mathrm{Ca}^{2+}$ were able to reduce the inhibitory effects of the phytoalexin. We suggested that 6-MM might interact with these metal cations which are essential for enzyme activity and for calmodulin activation (Amin et al., 1986). In this study (Table 1), we also found that the inhibitory effect of 6-MM on the uptake of ${ }^{3} \mathrm{H}$-labelled metabolites was reduced when a large amount of $\mathrm{Mg}^{2+}$ was added to the medium. Inhibition of cell growth (Fig. $4 a$ ) and the induced leakage of $260-\mathrm{nm}$-absorbing materials (Fig. $4 b$ ) caused by 6-MM depended on the 

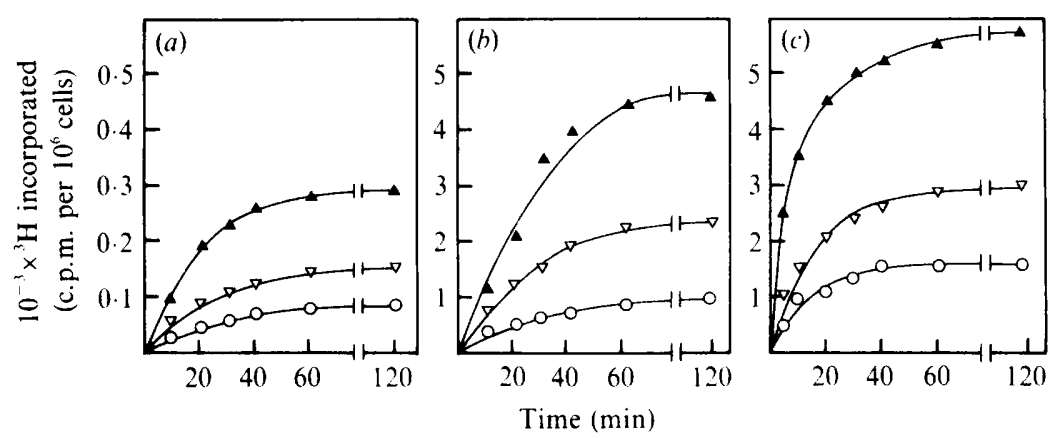

Fig. 3. Effect of 6-MM on the leakage of $(a)\left[{ }^{3} \mathrm{H}\right]$ thymidine, $(b)\left[{ }^{3} \mathrm{H}\right]$ uridine and $(c)\left[{ }^{3} \mathrm{H}\right]$ leucine from labelled cells of $C$. albicans. Suspensions of $C$. albicans in growth medium containing the labelled metabolites were kept at $27^{\circ} \mathrm{C}$ for $2 \mathrm{~h}$ on a reciprocal shaker. Labelled cells were collected by centrifugation, washed and resuspended in distilled water. 6-MM was added to the cell suspensions, and at intervals samples of the suspensions were taken out, filtered on a glass-microfibre filter and washed with water; the radioactivity in the filtrates was then counted. $\bigcirc$, Control; $\nabla, 6-\mathrm{MM}(0 \cdot 1 \mathrm{mM})$; $\Delta, 6-\mathrm{MM}(0.5 \mathrm{mM})$. Each point represents the mean of two separate experiments, the results of which agreed to within $10 \%$.

Table 1. Reversal by $\mathrm{Mg}^{2+}$ of the effect of $6-\mathrm{MM}$ on the uptake of $\left[{ }^{3} \mathrm{H}\right]$ thymidine, $\left[{ }^{3} \mathrm{H}\right]$ uridine and $\left[{ }^{3} H\right]$ leucine by $C$. albicans

C. albicans cells suspended in growth medium with the additions indicated were incubated with the ${ }^{3} \mathrm{H}$ labelled metabolites for $20 \mathrm{~min}$. Uptake was determined as described in Fig. 1, except that the cells were washed with cold water. Results are the means of three separate experiments $\pm \mathrm{SE}$.

\begin{tabular}{|c|c|c|c|}
\hline \multirow[b]{2}{*}{ Addition } & \\
\hline & {$\left[{ }^{3} \mathrm{H}\right]$ Thymidine } & {$\left[{ }^{3} \mathrm{H}\right]$ Uridine } & {$\left[{ }^{3} \mathrm{H}\right]$ Leucine } \\
\hline $\begin{array}{l}\text { None } \\
6-\mathrm{MM}(0.5 \mathrm{mM})\end{array}$ & $\begin{array}{l}4 \cdot 6 \pm 0.40 \\
1.9+0.15\end{array}$ & $\begin{array}{l}4.9 \pm 0.35 \\
2 \cdot 6+0.21\end{array}$ & $\begin{array}{r}10 \cdot 3 \pm 1 \cdot 60 \\
4 \cdot 8+0 \cdot 42\end{array}$ \\
\hline $\mathrm{MgSO}_{4}(10 \mathrm{mM})$ & $5.3+0.48$ & $4 \cdot 3+0 \cdot 15$ & $8.9+1.2$ \\
\hline $\mathrm{MgSO}_{4}(10 \mathrm{mM})+6-\mathrm{MM}(0.5 \mathrm{mM})$ & $3.6 \pm 0.51$ & $4 \cdot 2 \pm 0.37$ & $7.6 \pm 0.56$ \\
\hline
\end{tabular}

concentration of the divalent metal cations and were greatly reduced when these cations were present in high concentrations in the incubation medium. These results are analogous to those reported for the effect of these metal cations on the membrane disruption and growth inhibition of bacteria and fungi caused by polymyxin (Storm et al., 1977) and miconazole (Swamy et al., 1974), respectively. Kotani et al. (1977) also reported that ATP leakage from yeast cells treated with killer toxin was inhibited by the addition of $\mathrm{Ca}^{2+}$.

\section{Effect of 6-MM on the permeability of multilamellar liposomes}

Imai et al. (1975) showed that polymyxin-induced permeability changes of phospholipid liposomes require the presence of negatively charged amphipathic molecules such as dicetyl phosphate. On the other hand, the susceptibility of various membranes to the action of the antifungal agent amphotericin B requires the presence of sterols in the membrane (Bolard, 1986; Kerridge, 1986). In the experiment shown in Fig. 5, 6-MM induced the release of $\left[{ }^{14} \mathrm{C}\right]$ glucose trapped in liposomes constituted from phosphatidylcholine, dicetyl phosphate and cholesterol as well as those constituted from phosphatidylcholine alone. These results indicate that neither cholesterol nor negatively charged molecules are required for 6-MM-induced permeability changes in liposomes. The ability of 6-MM to alter the permeability of biological membranes seems to be independent of the presence of specific molecules such as sterols or negatively 


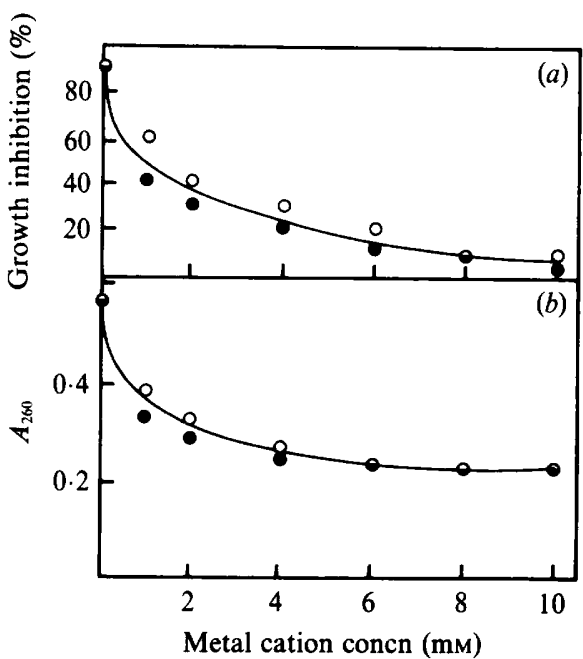

Fig. 4

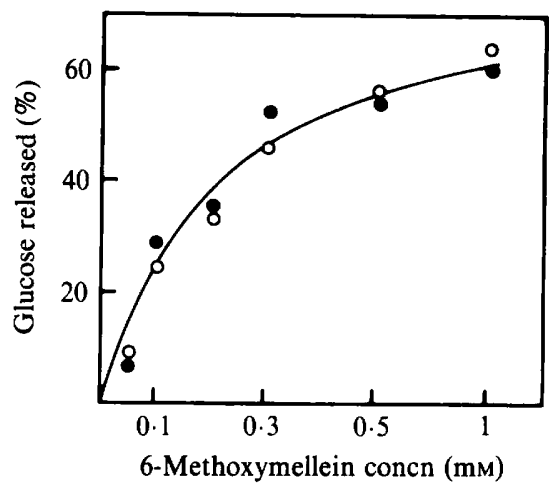

Fig. 5

Fig. 4. Reversal by metal cations of the effect of 6-MM on (a) cell growth and $(b)$ leakage of 260-nmabsorbing materials from cells of $C$. albicans. For the determination of the growth inhibition of $C$. albicans by 6-MM, C. albicans was precultured for $24 \mathrm{~h}$ in $5 \mathrm{ml}$ of growth medium supplemented with the indicated concentration of the metal cation. After the addition of 6-MM, the cultures were incubated at $27^{\circ} \mathrm{C}$ on a reciprocal shaker for further $24 \mathrm{~h}$ and the optical density at $595 \mathrm{~nm}$ of the cell suspensions was recorded. The optical density at $595 \mathrm{~nm}$ of controls without 6-MM was taken as $100 \%$. Experimental procedures for the determination of leakage of 260 -nm-absorbing materials were the same as in Fig. 2 except that salt solutions were supplemented with the indicated concentration of the metal cation. In this experiment, 6-MM concentration was $0.5 \mathrm{mM} . \mathrm{O}, \mathrm{Ca}^{2+} ; \mathrm{O}, \mathrm{Mg}^{2+}$. Each point represents the mean of three separate experiments with \pm SE less than $10 \%$ of the mean.

Fig. 5. Effect of 6-MM on the permeability of multilamellar liposomes. Multilamellar liposomes containing $\left[{ }^{14} \mathrm{C}\right]$ glucose were incubated at $22 \pm 2{ }^{\circ} \mathrm{C}$ with $6-\mathrm{MM}$ for $30 \mathrm{~min}$. Liposomes were separated by filtration through a membrane filter (Millipore GS; $0.2 \mu \mathrm{m}$ ) and the $\left[{ }^{14} \mathrm{C}\right] \mathrm{glucose}$ in the filtrate was measured. The total amount of $\left[{ }^{14} \mathrm{C}\right]$ glucose trapped in liposomes was taken as $100 \% . \mathrm{O}$, Liposomes constituted from phosphatidylcholine;, liposomes constituted from phosphatidylcholine, dicetyl phosphate and cholesterol (molar ratio 10:1:5). Each point represents the mean of two experiments, the results of which agreed to within $10 \%$.

charged molecules. This may explain the reason for the indiscriminate effects of this phytoalexin on eukaryotic and prokaryotic cells (Coxon et al., 1973; Kurosaki \& Nishi, 1983; Kurosaki et al., 1984), and suggests also that the membrane is the operative target for 6-MM toxicity in susceptible cells.

We are thankful to Dr Noriaki Takeguchi, Professor of this university, for his advice on the method of preparation of liposomes.

\section{REFERENCES}

AMIN, M., KURosaKI, F. \& Nishi, A. (1986). Inhibition of cyclic nucleotide phosphodiesterase by carrot phytoalexin. Phytochemistry 25, 2305-2307.

Amin, M., Kurosaki, F. \& Nishi, A. (1987). Carrot phytoalexin inhibits $\mathrm{Ca}^{2+}$, calmodulin dependent protein phosphorylation in carrot cells. Phytochemistry 26, 51-53.

Bangham, A. D., Standish, M. W. \& Watkins, J. C. (1965). Diffusion of univalent ions across the lamellae of swollen phospholipid. Journal of Molecular Biology 13, 238-252.
BOLARD, J. (1986). How do macrolide antibiotics affect cellular membrane properties? Biochimica et biophysica acta 864, 257-304.

Boydston, R., Paxton, J. D. \& Koeppe, D. E. (1983). Glyceollin, a site-specific inhibitor of electron transport in isolated soybean mitochondria. Plant Physiology 72, 151-155.

Coxon, D. T., Curtis, F. R., Price, K. R. \& Levett, G. (1973). Abnormal metabolites produced by Daucus carota roots under conditions of stress. Phytochemistry 12, 1881-1885. 
Dixon, R. A. \& KeY, P. M. (1983). Phytoalexins: enzymology and molecular biology. Advances in Enzymology 55, 1-69.

Fraser, R. S. S. \& Creanor, J. (1974). Rapid and selective inhibition of RNA synthesis in yeast by 8hydroxyquinoline. European Journal of Biochemistry 46, 67-72.

HARGREAVES, J. A. (1980). A possible mechanism for the phytotoxicity of the phytoalexin phaseollin. Physiological Plant Pathology 16, 251-357.

HsuChen, C.-C. \& Feingold, D. S. (1973). Polyene antibiotic action on lecithin liposomes. Effect of cholesterol and fatty acyl chains. Biochemical and Biophysical Research Communications 51, 972-978.

ImaI, M., INOUE, K. \& NoJima, A. (1975). Effect of polymyxin B on liposomal membranes derived from Escherichia coli lipids. Biochimica et biophysica acta 375, 130-137.

Kaplan, D. T., KeEn, N. T. \& Thomason, I. J. (1980). Studies on the mode of action of glyceollin in soybean. Incompatibility to root knot nematode Meloidogyne incognita. Physiological Plant Pathology 16, 319-325.

KERRIDGE, D. (1986). Mode of action of clinically important antifungal drugs. Advances in Microbial Physiology 27, 1-72.

Kotani, H., Shinmyo, A. \& Enatsu, T. (1977). Killer toxin for sake yeast: properties and effects of adenosine 5 '-diphosphate and calcium ion on killing action. Journal of Bacteriology 129, 640-650.
Kurosaki, F. \& NishI, A. (1983). Isolation and antimicrobial activity of the phytoalexin 6-methoxymellein from cultured carrot cells. Phytochemistry 22, 669-672.

Kurosaki, F., Matsui, K. \& Nishi, A. (1984). Production and metabolism of 6-methoxymellein in cultured carrot cells. Physiological Plant Pathology 25, 313-321.

OKu, N., NoJima, S. \& InOue, K. (1980). Selective release of non-electrolytes from liposomes upon perturbation of bilayers by temperature change or polyene antibiotics. Biochimica et biophysica acta 595, 277-290.

SMITH, D. R. (1982). In Phytoalexins. pp. 218-252. Edited by J. A. Bailey \& J. W. Mansfield. Glasgow \& London: Blackie \& Son.

Storm, D. R., Roesenthal, K. S. \& Swanson, P. E. (1977). Polymyxin and related peptide antibiotics. Annual Review of Biochemistry 46, 723-763.

Swamy, K. H., Sirsi, M. \& RaO, G. R. (1974). Studies on the mechanism of action of miconazole : effect of miconazole on respiration and cell permeability of Candida albicans. Antimicrobial Agents and Chemotherapy 5, 420-425.

Weinstein, L. I. \& Albersheim, P. (1983). Hostpathogen interactions. XXIII. The mechanism of the antibacterial action of glycinol, a pterocarpan phytoalexin synthesized by soybeans. Plant Physiology 72, 557-563. 